\title{
CDK Gene Mutation
}

National Cancer Institute

\section{Source}

National Cancer Institute. CDK Gene Mutation. NCI Thesaurus. Code C157553.

A change in the nucleotide sequence in a CDK family gene. 